\title{
A FAANYAG MECHANIKAI TULAJDONSÁGAINAK VÁLTOZÁSA ELTÉRÖ NEDVESSÉGTARTALMAK MELLETT
}

\section{THE CHANGES OF MECHANICAL PROPERTIES OF WOOD AT DIFFERENT MOISTURE CONTENT}

\author{
Vörös Ágnes ${ }^{1^{*}}$, Prof. Dr. Németh Róbert ${ }^{1}$ \\ ${ }^{1}$ Faanyagtudományi Intézet, Simonyi Károly Müszaki, Faanyagtudományi és Művészeti Kar, Soproni \\ Egyetem, Magyarország \\ https://doi.org/10.47833/2021.1.ENG.010
}

\section{Kulcsszavak: \\ mechanikai tulajdonságok \\ hajlítószilárdság \\ húzószilárdság \\ nyomószilárdság \\ Brinell-keménység}

\section{Keywords:}

mechanical properties

bending strength

tensile strength

compression strength

Brinell hardness

\section{Cikktörténet:}

Beérkezett 2020. július. 22.

Átdolgozva 2021. április 5.

Elfogadva 2021. április 15.
A cikk hat hazai, ipari szempontból jelentős fafaj, fehér akác (Robinia pseudocacia), kocsánytalan tölgy (Quercus petrea), közönséges bükk (Fagus sylvatica), nemes nyár (Pupulus $x$ euramericana), Iucfenyő (Picea abies) és vörösfenyő (Larix decidua) húzó-, hajlitó-, nyomószilárdság- és Brinell-Mörath keménység változását hivatott vizsgálni eltérő nedvességtartalmak mellett.

\begin{abstract}
The purpose of the article is, to review changes in tensile strength, compression strength, bendingstrength, Brinell-Mörath hardness atdifferent moisture content of Robinia pseudocacia, Quercus petrea, Fagus sylvatica, Pupulus, Picea abies and Larix decidua.
\end{abstract}

\section{Bevezetés}

A faanyag fizikai-mechanikai tulajdonságai, teherbírása, így felhasználhatósága is több tényező együttes hatásának eredménye. Az évgyürüszerkezet, az ebböl fakadó inhomogén felépítés, az ortogonális anizotrópia, a porózus tulajdonság, az adott fafajra jellemző, eltérő sejtszerkezet, a faanyag nedvességtartalma, az esetlegesen elöforduló fahibák mind-mind nagy jelentőséggel, befolyásoló szereppel bírnak, amit nem szabad figyelmen kívül hagyni[2].

\footnotetext{
* Kapcsolattartó Vörös Ágnes. Tel.: +36-70/6732-344; fax: -

E-mail cím: voros.agnes@phd.uni-sopron.hu
} 


\section{A nedvességtartalom hatása a mechanikai tulajdonságokra}

Az élő fa müködése szempontjából a szabad víznek van nagyobb jelentősége, míg - müszaki, szilárdságtani tulajdonságokra gyakorolt hatásából kifolyólag - a kötött víz a használhatóságot befolyásolja jobban. Körülbelül $6 \%$ nedvességtartalomtól a rosttelítettségi állapotig ez a szilárdságcsökkenés közel lineárisnak tekinthetö. Ebben a tartományban. Az $1 \%$ nettó nedvességtartalom-változásra jutó szilárdságváltozást az a átszámítási tényező fejezi ki, értékei a különböző szilárdságtípusok esetében az alábbiak szerint módosulnak(1. táblázat):

\section{Táblázat. Az a átszámitási tényező értékei a különböző szilárdságtípusok}

\begin{tabular}{|l|l|}
\hline Szilárdságtípus & $\alpha$ átszámítási tényező értéke \\
\hline nyomószilárdság - rostirányban & 0,04 \\
\hline hajlító szilárdság & 0,04 \\
\hline húzószilárdság & 0,03 \\
\hline
\end{tabular}

A szilárdsági vizsgálatok elvégzésének nemzetközi megállapodás szerinti paraméterei: $20^{\circ} \mathrm{C}$ hömérséklet, $65 \%$ légnedvesség, és $12 \%$ fanedvesség. Amennyiben ettől eltérő nedvességtartalmú próbatesteken kívánunk mérést elvégezni, rosttelítettségi tartomány alatti nedvességtartalom esetében a szilárdságváltozás a következőképpen számítható át:

$$
\sigma_{12}=\sigma_{u} \cdot(1+\alpha \cdot(u-12))(\mathrm{MPa})
$$

ahol:

$\sigma_{12} \quad-12 \%$-os nedvességtartalomhoz tartozó szilárdság értéke

$\sigma_{u} \quad-u$ nedvességtartalomhoz tartozó szilárdság értéke

u - próbatest nedvességtartalma

a - átszámítási tényező

A fenti egyenletet általános alakban felírva azt kapjuk, hogy a szilárdságcsökkenés felfogható a kezdeti szilárdság értékének és a határfeszültség csökkentő tényezőnek a szorzataként is. A határfeszültség csökkentő tényezőt 12-30 \%-os tartományon belül értelmezzük. Ebből következik, hogy az (1) egyenlet is csak e tartományon érvényes [4].

\section{Kutatási anyagok és módszerek}

\subsection{Kutatási anyagok}

A kutatás során arra törekedtünk, hogy a hazai ipar szempontjából jelentős, lombos fafajok kerüljenek kiválasztásra, így fehér akáccal (Robinia pseudocacia), kocsányos tölggyel (Quercus robur), közönséges bükkel (Fagus sylvatica) és nemes nyárral (Pupulus) dolgoztunk. A fafajok meghatározásánál fontos szempont volt a sürüség, porozitás, mint a mechanikai tulajdonságokkal legegyértelmübben kapcsolatba hozható fizikai anyagjellemző, így az alábbiakat választottuk:

- magas sürüségüek $\left(700 \mathrm{~kg} / \mathrm{m}^{3}<\right)$ : fehér akác, közönséges bükk

- közepes sürüségü $\left(550-700 \mathrm{~kg} / \mathrm{m}^{3}\right)$ : kocsányos tölgy

- alacsony sürüségű $\left(550 \mathrm{~kg} / \mathrm{m}^{3}>\right.$ ): nemes nyár[2]

A faanyagok meghatározásában további fontos kritériumot képzett, hogy legyen köztük szórtlikacsú (közönséges bükk, nemes nyár) és gyürüs likacsú (kocsányos tölgy, fehér akác) is.

A méréstorzító tényezők kiküszöbölése érdekében kizárólag hibamentes, azonos szálirányú, ezáltal homogénebb szerkezetű mintát vizsgáltunk.

A méréseket megelőzően az adott vizsgálat szabványában előírt próbatestek lettek kialakítva, melyeket két csoportra osztottunk, mindkét csoportba azonos mennyiségü próbatest került. A két csoportot klímaszekrényekbe helyeztük tömegállandóságig, így biztosítva a kívánt $6 \%$-os, illetve $20 \%$-os nedvességtartalmat. 


\subsection{Kutatási módszerek}

A kutatási módszerek kiválasztásánál a leggyakrabban használt, szabványos kutatási módszereket preferáltuk: húzó-, hajlító- és nyomószilárdságot vizsgáltunk, valamint a Brinell-Mörath keménységet. A cél ezen értékek egymástól való függésének meghatározása, számszerüsítése volt.

\subsubsection{Húzószilárdság jelentősége, meghatározása}

Húzószilárdságon a fának a húzással szemben kifejtett ellenállását értjük [3]. A faiparban inkább technológiai, mintsem szerkezeti jelentőséggel bíró mechanikai tulajdonság, furnérgyártásban, forgácslapok gyártásánál jut nagyobb szerephez. A terhelés irányultsága meghatározó: a fa rostokkal párhuzamosan jóval ellenállóbb húzásra, mint rostokra merőlegesen. Ez főként anatómiai tényezőkre vezethető vissza: a mikrofibrillák lefutása a sejtfal S2 rétegében, vagyis a rostlefutási szög (MFA), az évgyürüszerkezet, valamint a faanyagok rostos felépítése. Gyakoribb az anyag rostokkal párhuzamosan történő vizsgálata [2].

A húzószilárdság értékét a legnagyobb mért terhelés és a próbatest keresztmetszeti területének hányadosa adja:

$$
\sigma=\frac{F_{\max }}{A}(\mathrm{MPa})
$$

ahol:

$\sigma \quad$ - húzószilárdság

$F_{\max } \quad$ - legnagyobb központos húzóerö $\quad(\mathrm{N})$

A - húzásra igénybevett keresztmetszet területe (mm2)

A maximálisan elért húzóerő mértékén túl következtethetünk a faanyag minőségére abból is, hogy próbatest milyen törésképet mutat a vizsgálat után.

A próbatestek az ISO13061-6 szabványban leírtaknak megfelelően lettek kialakítva: 20 × 20 × 300 $\mathrm{mm}$ befoglaló méretűek.[8]

\subsubsection{Hajlítószilárdság jelentősége, meghatározása}

A bútoriparban illetve az építőiparban kiemelkedő szerepű szilárdságtípus, gondoljunk csak a gerendákra, vagy a 14-es számú Thonet székre. Faanyagnál hárompontos terhelési séma esetén értékét a Navier-egyenlet Tanaka által korrigált formájával számítjuk [1]:

$$
\sigma=\frac{F_{\max }}{A}(\mathrm{MPa})
$$

ahol:

$\begin{array}{cll}\sigma & - \text { nyomószilárdság } & (\mathrm{MPa}) \\ \text { Fmax } & - \text { legnagyobb terhelőerő } & (\mathrm{N}) \\ \mathrm{A} & - \text { nyomásra igénybevett keresztmetszet területe } & (\mathrm{mm} 2)\end{array}$
során [7].

A vizsgálatra vonatkozó szabványt (ISO13061-3) figyelembe vettük a vizsgálatok elvégzése

\subsubsection{Nyomószilárdság keménység jelentősége, meghatározása}

A fának a rostokkal párhuzamosan vagy azokra merőleges irányban történő terheléssel szemben kifejtett ellenálását nevezzük nyomószilárdságnak. Mivel faszerkezetekben és számos fatermékekben is gyakran fellépnek nyomóigénybevételek, e mechanikai tulajdonság jelentősége sem elhanyagolható.

A nyomószilárdság mértékét a legnagyobb terhelö erő és a nyomással terhelt felület hányadosa adja:

$$
\sigma=\frac{F_{\max }}{A}(\mathrm{MPa})
$$


ahol:

$\sigma \quad$ - nyomószilárdság

Fmax - legnagyobb terhelöerö

A - nyomásra igénybevett keresztmetszet területe

Vizsgálataink során a rostokkal párhuzamos irányú nyomószilárdságot vizsgáltuk az ISO13061-17 szabványban leírtaknak megfelelően [9].

\subsubsection{Brinell-Mörath keménység jelentősége, meghatározása}

Keménység alatt gyakorlati értelemben az anyagnak azt az ellenállását nevezzük, amelyet az anyag a szerszám behatolása ellen kifejt. Brinell a keménységet a golyót terhelő erő és az acélgolyó által benyomott felület hányadosaként fejezte ki, a vizsgálathoz $10 \mathrm{~mm}$ átmérőjü golyót használt, mint nyomótestet. Mörath módosítási javaslatára, az MSZ6786/11-82 szabvány szerint az igen kemény fafajokat $100 \mathrm{~N}$, a középkemény fákat $500 \mathrm{~N}$, a nagyon puha fákat pedig $100 \mathrm{~N}$ terhelésnek tesszük ki [4][6][10].

A benyomódási mélység az alábbi képlettel számítható (1):

ahol:

$$
h=\frac{D-\sqrt{D^{2}-d^{2}}}{2}(\mathrm{~mm})
$$

h - benyomódás mélysége

$(\mathrm{mm})$

d - golyó benyomódásából keletkező gömbsüveg átmérője

D - golyó átmérője

Ez alapján a Brinell-féle keménység (2):

$(\mathrm{mm})$

$$
H_{B}=\frac{F}{D \pi h}=\frac{2 F}{D \pi\left(D-\sqrt{D^{2}-d^{2}}\right)}\left(\mathrm{N} / \mathrm{mm}^{2}\right)
$$

ahol:

$\mathrm{H}_{B}$ - Brinell-féle keménység

$\mathrm{F}$ - terhelőerő

$\left(\mathrm{N} / \mathrm{mm}^{2}\right)$

D - golyó átmérője

$(\mathrm{N})$

$\mathrm{h}$ - benyomódás mélysége

$(\mathrm{mm})$ 


\section{Eredmények}

A szabványos vizsgálatok elvégzése után a későbbiekben megjelenített átlagértékeket kaptuk: Narancssárga - $6 \%$ nedvességtartalom mellett mért értékek Citromsárga - 20\% nedvességtartalom mellett mért értékek

Világos zöld - légszáraz állapotú, $12 \%$-os nedvességtartalmú mintákra vonatkozatott átlagos irodalmi értékböl az 1. táblázat és az 1. képlet alapján 20\%-os nedvességtartalomra átszámított átlagos értékek.

Az eredeti irodalmi adatok Molnár S. (2004) és Kovács I. (1979) munkáiból származnak.

\subsection{Húzószilárdság}

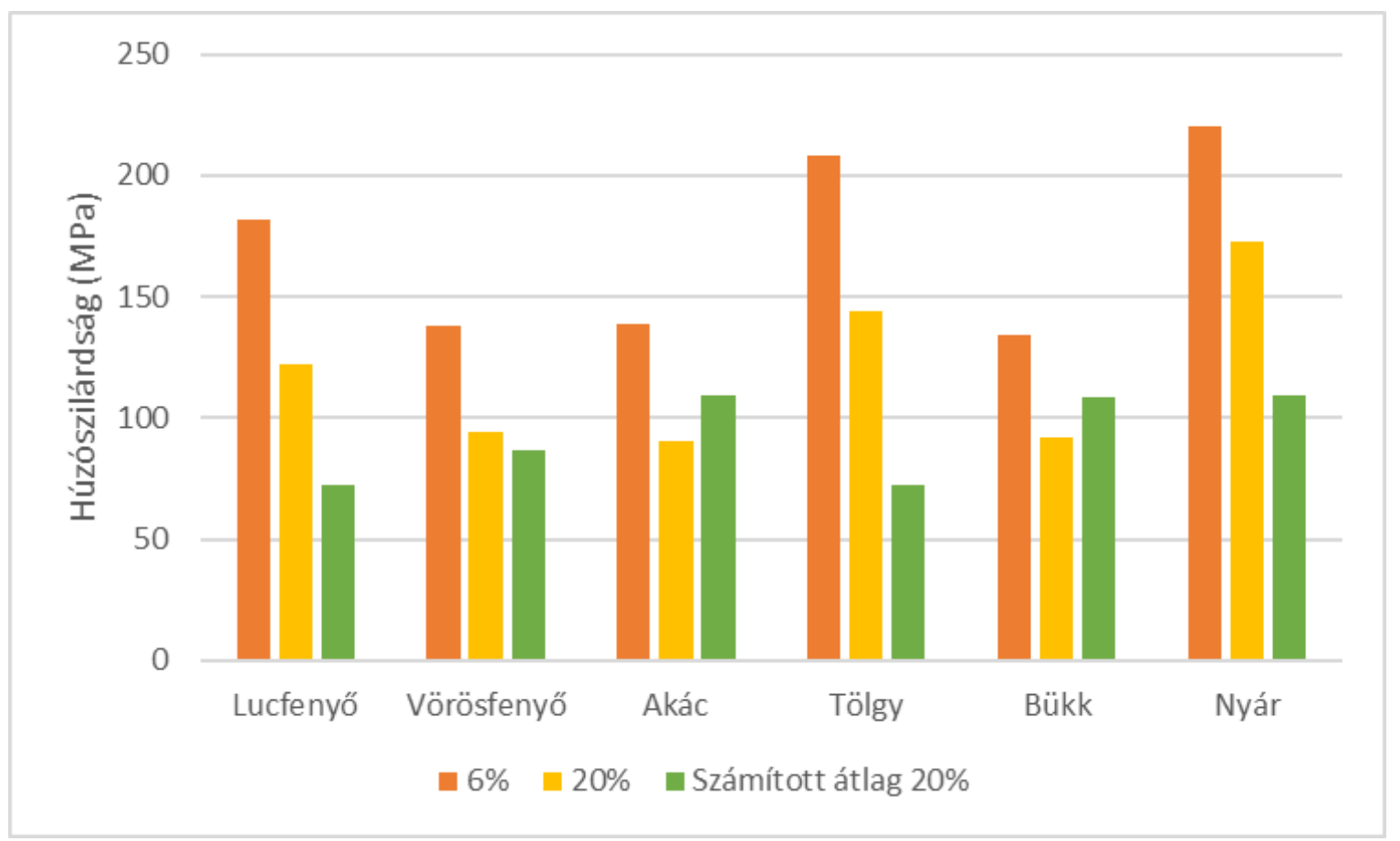

1. ábra. A húzószilárdság változása a nedvességtartalom függvényében lucfenyő, vörösfenyö, akác, tölgy, bükk és nyár fafajok esetén

Ahogy az 1. ábrán is jól kivehető, az általunk $20 \%$-os nedvességtartalmon mért húzószilárdsági értékek az akác és a bükk kivételével jócskán meghaladják az átlagos értékeket. $A$ különbség azonban nem tekinthető szignifikáns eltérésnek, hiszen a faanyagok fajon belül is eltérö szövetszerkezetükböl adódóan más-más mechanikai-fizikai tulajdonságokkal bírhatnak. Ez a jelenség - sok egyéb más mellett - az ökológiai-, erdőművelési-, anyagösszetételi-, növekedési tényezőktöl, törzsön belüli elhelyezkedéstöl is függ.

A nedvességtartalom növekedés hatására bekövetkezett szilárdságcsökkenés lucfenyőnél 60,2 MPa (33\%), vörösfenyőnél 43,6 MPa (32\%), akácnál 48,7 MPa (35\%), tölgynél 63,1 MPa (31\%), bükknél $42 \mathrm{MPa}(31 \%)$, nyárnál 47,4 MPa (22\%). 


\subsection{Hajlító szilárdság}

A hajlítószilárdság értékei a 2. ábrán látható módon változtak.

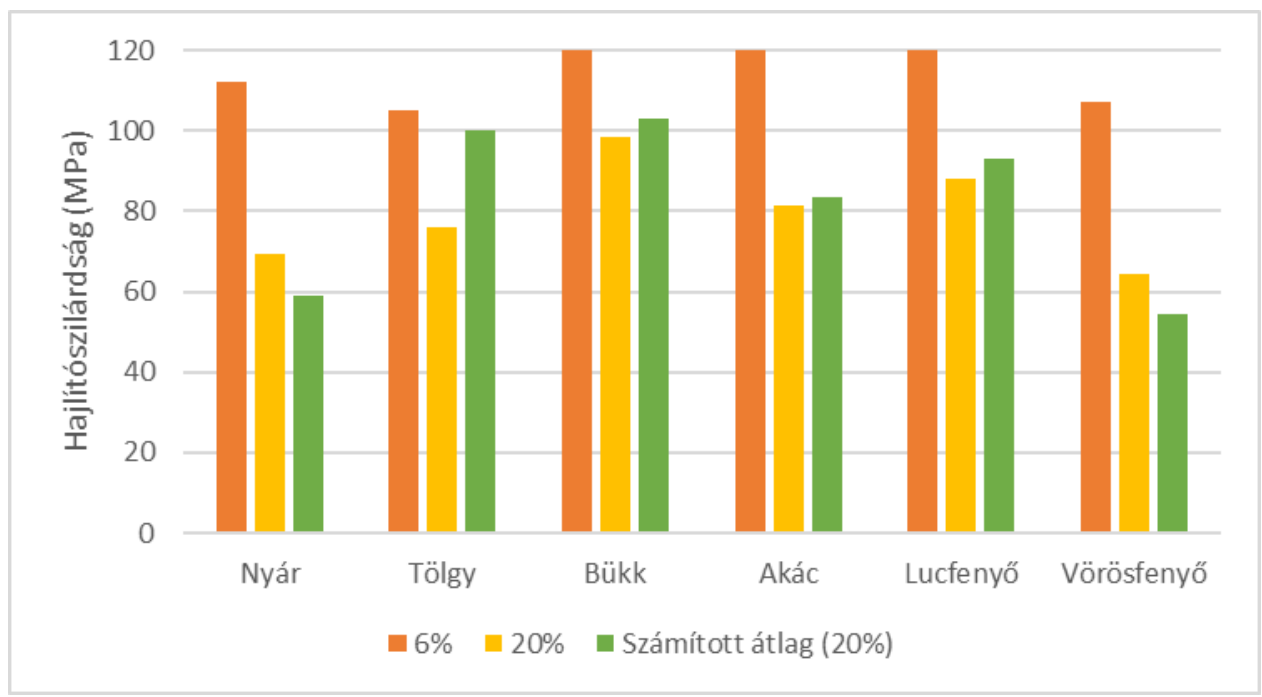

2. ábra. A hajlítószilárdság változása a nedvességtartalom függvényében lucfenyő, vörösfenyő, akác, tölgy, bükk és nyár fafajok esetén

A különböző fafajok esetében igen eltérő a szilárdságcsökkenés mértéke: lucfenyőnél $47 \mathrm{MPa}$ (35\%), vörösfenyőnél $43 \mathrm{MPa}(40 \%)$, akác esetén $42 \mathrm{MPa}(34 \%)$, tölgynél $29 \mathrm{MPa}(28 \%)$, bükknél $69 \mathrm{MPa}(41 \%)$, nyárnál pedig $43 \mathrm{MPa}(38 \%)$.

Ami az irodalmi értékekkel való összehasonlítást illeti a nyár és vörösfenyő fafajok meghaladták az átlagértéket. A többi fafaj - ha nem is jelentősen- alatta maradt ugyan az átlagnak, de a minimum irodalmi értéknél jócskán magasabb lett. Az okok ebben az esetben is főként a fafajok, közti különbségekben illetve az anatómiában keresendők, de természetesen okozhatja a származási hely illetve a termőhelyi adottságok is.

\subsection{Nyomószilárdság}

Nyomószilárdsági vizsgálatra kapott eredményeinket, összehasonlító irodalmi értékeket az 3. ábra szemlélteti.

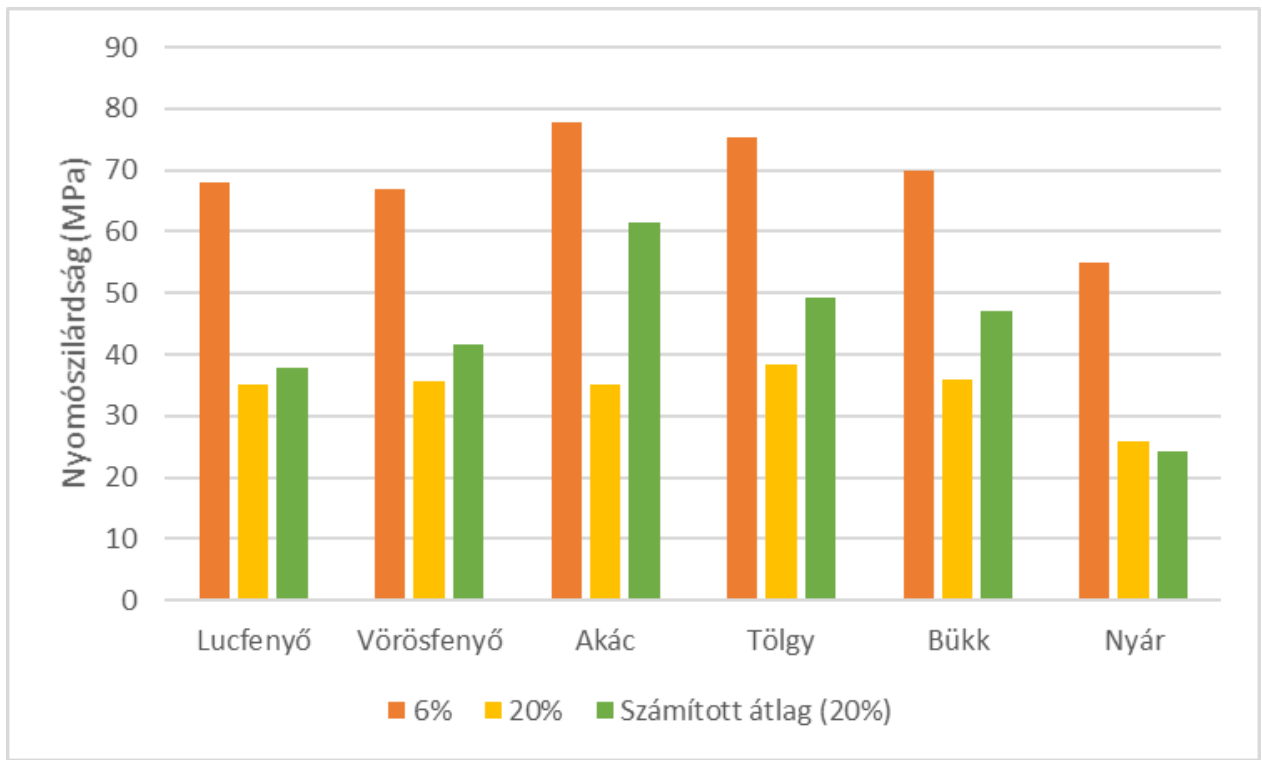

3. ábra. A nyomószilárdság változása a nedvességtartalom függvényében lucfenyö, vörösfenyö, akác, tölgy, bükk és nyár fafajok esetén 
A nyomószilárdság átlagosan 50 \% csökkenést mutatott a vizsgált eltérő nedvességtartalmak mellett. Értékeiket tekintve egyedül a nyárból készült próbatestek nyomószilárdsága haladja meg az átlagot, a többi fafajé alatta marad. Ennek ellenére itt sem beszélhetünk jelentős eltérésről.

\subsection{Brinell-Mörath keménység}

A keménység értékeit mindhárom anatómiai irányban megvizsgáltuk, ezeket mutatják be a 4. ábra:

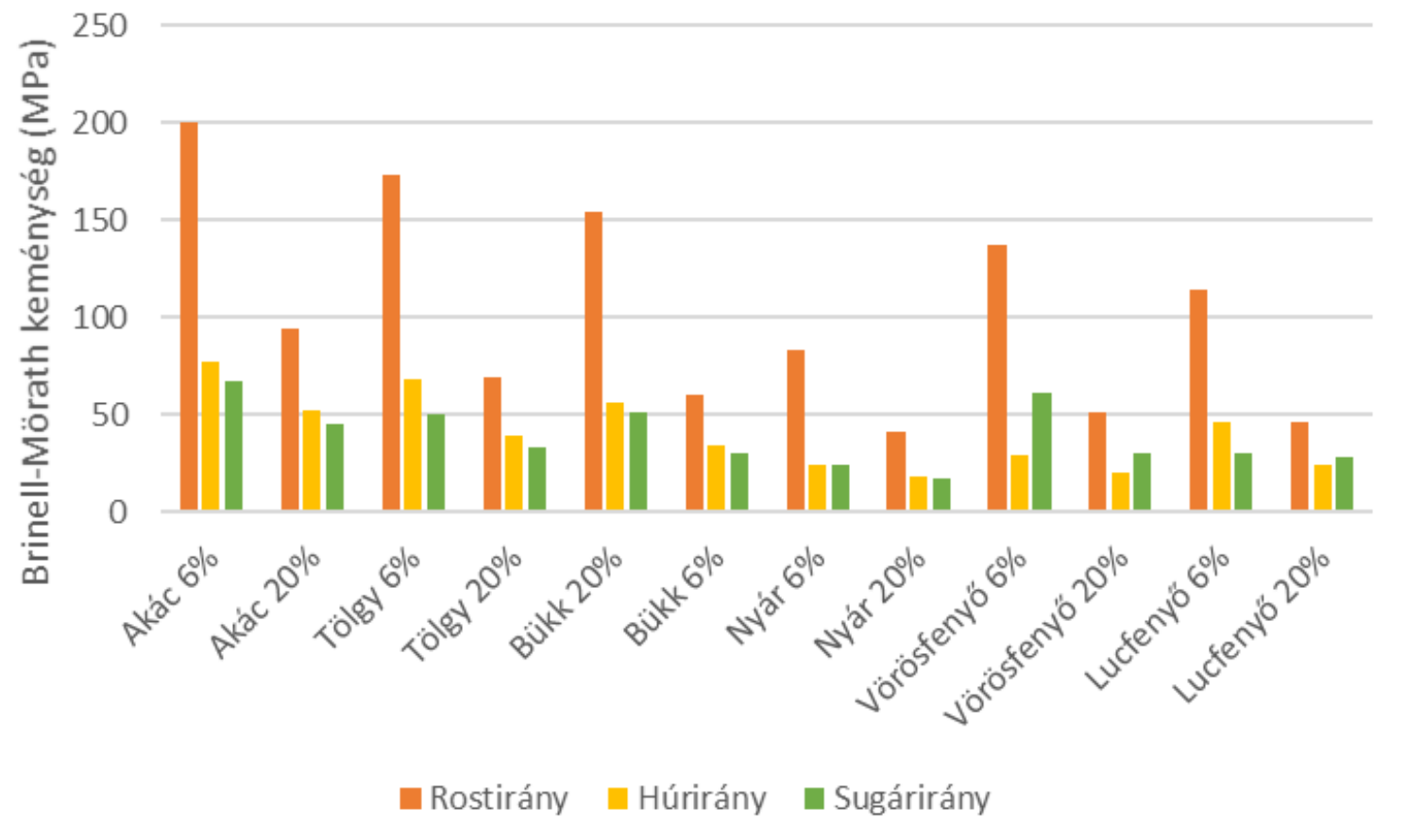

4. ábra. A Brinell-Mörath keménység változása a nedvességtartalom függvényében lucfenyő, vörösfenyő, akác, tölgy, bükk és nyár fafajok esetén a három fö anatómiai irányban

A számos adat könnyebb összehasonlíthatósága érdekében a keménységcsökkenés mértékét táblázat formájában ismertetjük (1. táblázat):

1.Táblázat. A Brinell-Mörath keménység csökkenése a különböző anatómiai irányokban légszáraz nedvességtartalomról rosttelítettségi tartomány fölé lucfenyő, vörösfenyő, akác, tölgy, bükk és nyár fafajok esetén

\begin{tabular}{|c|c|c|c|c|c|c|}
\hline & Akác & Tölgy & Bükk & Nyár & Vörösfenyő & Lucfenyő \\
\hline Rostirány & $53 \%$ & $60 \%$ & $61 \%$ & $50 \%$ & $62 \%$ & $58 \%$ \\
\hline $\begin{array}{c}\text { Sugár- } \\
\text { irány }\end{array}$ & $36 \%$ & $55 \%$ & $39 \%$ & $25 \%$ & $32 \%$ & $47 \%$ \\
\hline Húrirány & $32 \%$ & $38 \%$ & $40 \%$ & $30 \%$ & $50 \%$ & $5 \%$ \\
\hline
\end{tabular}

Ahogy látható, a különböző fafajok anatómiai irányonként vett keménységcsökkenése egészen eltérő. Míg rostirányban jellemzően 50-60\%-os szilárdságcsökkenést tapasztalhatunk, sugár- és húrirányban jelentős különbségek mutatkoztak. Akác és nyár esetén $30 \%$ körüli szilárdságcsökkenést tapasztalhattunk mindkét irányban, bükknél ugyanez már közel $40 \%$ volt. Tölgynél a sugárirányú szilárdságcsökkenés mértéke a húrirányénak majd' másfélszerese (55\%) volt. Vörösfenyőnél hasonló volt az arány, de húrirányban mutatkozott nagyobb értékcsökkenés. 
Lucfenyő esetén egészen tangenciálisan alacsony, mindössze $5 \%$-os volt a csökkenés mértéke, míg radiális irányan közel felére csökkent a nedvességtartalom növekedésével.

A nyár és a tölgy ily jelentős szilárdságcsökkenésére anatómiai sajátosságaik adhatnak magyarázatot: míg a tölgyben nagyméretü üregek vannak, a nyárban pedig (tölgyhöz mérten kisebb, szórtlikacsúakhoz képest nagyobb méretü) több, térfogatarányának mintegy fele mennyiségü edényt találhatunk, ezért e fafajok arányaikban jóval több vizet képesek magukba szívni.

Összegzésképpen elmondható, hogy a vizsgálat során kapott adatok jól közelítik a szakirodalmi értékeket, igazolva ezzel a mérési metódusaink helyességét. Feltétlenül szükséges, hogy más nedvességtartalmak mellett is elvégezzük ugyanezeket a vizsgálatokat, s a kapott adatok összehasonlíthatók legyenek. Hogy átfogóbb képet kaphassunk a különböző szilárdságtípusok egymással való (matematikai) kapcsolatáról, további nedvességtartalmak mellett elvégzett kutatási adatokra lenne szükség.

\section{Köszönetnyilvánítás}

A kutatás az Emberi Erőforrások Minisztériuma ÚNKP-19-3-I kódszámú Új Nemzeti Kiválóság Programjának támogatásával készült.

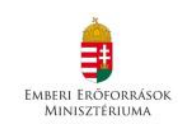

\section{Irodalomjegyzék}

[1] Kovács I. (1979): Faanyagismerettan. Mezőgazdasági Kiadó, Budapest.

[2] Molnár S. (2004): Faanyagismeret. Mezőgazdasági Szaktudás Kiadó, Budapest ISBN 9639553174

[3] Molnár S., Farkas P., Börcsök Z., Zoltán Gy. (2016): Földünk ipari fái. Erfaret, Sopron. p. 28 ISBN 978-963-12-5239-2

[4] Sitkei Gy. (1994): A faipari műveletek elmélete. Mezőgazdasági Szaktudás Kiadó, Bp.; pp. 21-25., 105-106, 109, 211-213

[5] Vörös Á., Prof. Dr. Németh R. (2018): A faiparban használt keménységvizsgálati eljárások történeti fejlödése 1. Statikus keménységvizsgálati eljárások 1915-ig. Gradus, Kecskemét. VOL 5, No1 pp 113-120

[6] Vörös Á., Prof. Dr. Németh R. (2018): A faiparban használt keménységvizsgálati eljárások történeti fejlődése 2. Statikus keménységvizsgálati eljárások 1915-1950. Gradus, Kecskemét. VOL 5, No 2 pp. 178-187

[7] ISO13061-3

[8] ISO13061-6

[9] ISO13061-17

[10] MSZ6786/11-82 